\title{
Spor ve Mantık İlişkisi
}

\author{
Hülya Altunya \\ Süleyman Demirel Üniversitesi, Illahiyat Fakültesi, Mantık Anabilim Dalı. ORCID ID: 0000-0003-2115-5207
}

\begin{abstract}
Özet
Spor ve mantık, bedeni ve zihni disipline eden ve düzenli olarak tatbik edildiğinde her ikisinin de sağlıklı çalışmasına imkan veren kurallardan ibarettir. Adeta bedeni olumlayan bir düşünme biçimiyle spor eğitimi, insanın bilgeliğini kazanmasını sağlayan bilgiler bütününden olușur. Buna karșılık mantık ise zihnin doğru düșünmesinin garantisini veren kurallardan teșekkül eder. Antik Yunan'da Platon ve Aristoteles, spor ve mantığın insan bedeni ve zihni üzerindeki önemi ve değeriyle ilgili olarak görüş açıklayan ilk filozoflardır. Platon, çocuklara ve gençlere fiziksel hareketlerin öğretilerek bedenlerin güçlü, sağlıklı ve estetik bakımdan güzel olmalarını önermektedir. Buna karșılık Aristoteles, mantık biliminin kurucusu olarak zihinlerin doğru ve ölçülü düşünebilmesinin yolunu inșa eder. Buna göre kurallarına uyularak tatbik edildiğinde mantık, zihnin hataya düșmesini engelleyen alet ilmidir. Öte yandan spor, insan bedeni için faydalı olan fiziksel hareketlerin nasıl yapılması gerektiğini açıklayan ve böylece bedenin ölçülü ve dengeli bir yapıya sahip olmasını sağlayan bilimdir. Yani zihnin sağlıklı işleyişinin ölçütü mantık ise sağlıklı bedenin ölçütü de spordur. Farklı kategorilerde olmakla birlikte birer değer olmaları bakımından beden ve zihin, düşünen/konuşan canlı (hayavanü’n-natık) şeklinde tanımladığımız insanı olușturan temel yapıdırlar. Spor ve mantık ise bu temel yapının formudurlar. Bu araștırmada öncelikle sporun ne'liğini sorunsallaștırarak mantıksal tahlillerle onun mahiyetini açığa çıkartmayı deneyeceğiz. Daha sonra mantığın ne'liği üzerinde duracağız. Mantıksal düşünme, eleștirel düşünme, yaratıcı düşünme, sezgisel düşünme vb. düşünme çeşitleriyle bağlantılı olarak spor ve mantık arasındaki ilişkiyi tartışmaya çalışacağız.
\end{abstract}

Anahtar Kelimeler:Spor, Mantık, Ölçü, Zihin, Beden.

\section{Relationship between Sport and Logic}

\begin{abstract}
Sport and logic consist of the rules that discipline the body and mind and allow for both to work properly when applied regularly. In fact, with a way of thinking that accepts the body, sport education is a set of information that enables man to gain his wisdom. On the other hand, logic consists of rules that guarantee the right thinking of the mind. In Ancient Greece, Plato and Aristotle were the first philosophers to express their views on the importance and value of sport and logic on the human body and mind. Plato focuses on teaching physical training to children and young people, to make them strong, healthy and aesthetically beautiful. At the same time Aristotle, the founder of the science of logic, builds the way for minds for restrained and correct thinking. When applied according to these rules, logic is the tool that prevents the mind from falling into error. On the other hand, sport is a movement which consists of movements which are beneficial for human body and provides a measured and balanced structure of the body. That is, if the criterion for functioning of the mind is logic, then sport is the measure for functioning of the body. In terms of being values, the body and the mind are the basic structures that make up the human being defined as the thinking / speaking animal. Sports and logic are the form of this basic structure. In this research, firstly we will try to reveal the nature of the sport and investigate it with logical analyzes. Then we will focus on the essence of logic. Finally, we will discuss the relationship between sport and logic relative to the kinds of thinking such as logical thinking, critical thinking, creative thinking, intuitive thinking etc.
\end{abstract}

Key Words: Sport, Logic, Measure, Mind, Body.

\section{Giriș}

İnsan aklının ölçütü olarak mantık ve bedenin ölçütü olarak spor, zihne ve bedene form kazandıran, sağlıklı çalışmasını sağlayan zihinsel ve fiziksel iki ayrı etkinliktir.

*Yazışma Adresi / Address for Correspondence: Hülya Altunya, Email: hulyaaltunya@sdu.edu.tr

Geliş Tarihi / Received Date: 27.11.2018

Kabul Tarihi / Accepted Date: 09.12.2018

Doi: $10.26701 /$ uad. 488266
Her iki etkinliğin ortak geçmiși, Antikçağ Yunan şehir devletlerine kadar geri götürülebilir. ${ }^{1}$ Mantık bilim olarak Aristoteles (M.Ö. 384-322) tarafından inşa edilirken, sporun bilim olarak ortaya çıkışı modern döneme kalmıştır. Ancak gerek Aristoteles gerekse de hocası Platon (M.Ö. 427-347), -döneminin adlandırmasıyla- jimnastiğin veya fiziksel hareketlerin insan bedeninin ve zihninin sağlıklı

\footnotetext{
${ }^{1}$ Spor ve olimpiyatlar Antikçağ Yunan şehir devletlerinden önce Mısır, Anadolu ve Mezopotamya'da yapılmaktaydı. Ancak Antikçağ Yunan şehir devletlerinde olimpiyatlar, dini nitelikli bir etkinliktir. Ali Tekin, Gülcan Tekin, "Antik Yunan Dönemi: Spor ve Antik Olimpiyatlar Oyunu", Tarih Okulu Dergisi, Yıl: 7, Sayı: XVIII, Haziran 2014, (ss. 121-140), s. 137.
} 
çalışmasındaki önemini ve değerini eserlerinde ele almak suretiyle 'spor bilimleri'nin teorik kısmını hazırlayan düşüncelerine eserlerinde yer vermişlerdir. Ayrıca bu dönemde spor etkinlikleri, sadece sağlık amaçlı fiziksel hareketler olarak kalmayıp, olimpiyatların ortaya çıkmasıyla birlikte dinsel bir nitelik de kazanmıştır.

Antikçağ'da spor veya fiziksel hareketler, bedenin sağlığ 1 ve estetik görünümü açısından değerli olduğu kadar bedenden daha değerli olan ruhun veya zihnin sağlığı için de birincil derecede önemlidir. Bu nedenle Platon için spor, en az matematik ve müzik kadar gerekli bir etkinliktir. $^{2}$ Ayrıca Platon'un ütopik devlet yapılanmasında devletin koruyucularının ve kahraman savaşçıların, kendi adlarını ölümsüzleştirebilmek için spor yapmalarının gerekliliği üzerinde durulur. Bunun için ise onların, düzenli yapılan fiziksel hareketlerle bedenlerinin ideal formunu muhafaza etmelerine dikkat çekilir. Özellikle gençlerin beden, zihin ve ruh gelişimleri için jimnastik eğitimi, sıkı bir şekilde uygulanması gereken fiziksel hareketlerdir. ${ }^{3}$ Burada ilk olarak mantığın ve sporun ne'liğine değinildikten sonra Platon ve Aristoteles'in görüşleri bağlamında bu iki etkinlik arasındaki ilişki, mantıksal düşünme, eleştirel düşünme, yaratıcı düşünme, sezgisel düşünme vb. düşünme biçimleri açısından incelenecektir. Daha sonra ise mantıksal düşünmenin spor bilimine ne tür faydalar sağlayacağı ele alınacaktır.

\section{SPORUN NE’LiĞi}

Spor, çeşitli fiziksel hareketlerin ölçülü ve belirli bir biçimde yapıldığı teknik ve estetik eylemler bütünüdür. Bu eylemler insanın doğasında bulunmasına rağmen bunlar, belirli, düzenli, ölçülü ve kurallı oynanan bir oyun olması yönüyle ise yapaydır. ${ }^{4}$ Zira bu hareketlerle insan, belirli bir form kazanmaktadır. Her ne kadar insan, diğer hayvanlarda olduğu gibi doğal olarak hareket etme, zıplama, eğilip doğrulma vb. eylemleri yapma imkanına sahip olsa da, bu hareketleri spor etkinliklerine dönüştürebilen tek canlı türüdür. Hatta insan bu özelliğiyle, spor yapan canlı olarak tanımlanmıștır. Burada insan, kendinde bulunan doğal yetilerini eğitmekle öncelikle bedenini ve daha sonra da zihnini ve ruhunu verimli bir biçimde kullanma imkanına sahip olmaktadır. Diğer taraftan sporun 'oyun' niteliğini taşıması, insanda, özellikle zihinsel açıdan gelişimi sağlamaktadır. Oyunun özgürlükle birlikte kurallılığı da öğretmesi ve yaşatması, insanın, kurallara uyarak çeşitli alternatifler arasından başarıya götürecek olanı bulmaya zorlamaktadır. Aslında insan sonucu belirsiz olan oyunda, kuralların çerçevesinin dışına çıkmadan tüm ihtimalleri düşünmeye çalışarak, bunlar arasından 'en doğrusu'nu tercih ederek, seri bir şekilde çıkarımlar yaparak

\footnotetext{
${ }^{2}$ Plato, Second Alcibiades, (Complete Works içinde), ed. John M. Cooper, Hackett Publishing Company, USA, 1997, s. 604; Rival Lovers, (Complete Works içinde), ed. John M. Cooper, Hackett Publishing Company, USA, 1997, s. 622-623. ${ }^{3}$ Plato, Alcibiades, Complete Works içinde), ed. John M. Cooper, Hackett Publishing Company, USA, 1997, s. 563, 576, 586; Plato, Crito, Complete Works içinde), ed. John M. Cooper, Hackett Publishing Company, USA, 1997, s. 44-45. ${ }_{4}^{4}$ Attila Erdemli, Temel Sorunlarıyla Spor Felsefesi, E Yayınları, III. Basım, İstanbul, 2016, s. 38.
}

sonuca ulaşmaktadır. Șu halde spor, ister 'oyun' isterse de sadece fiziksel hareketler olması bakımından mantıksal çıkarımlar yapmayla doğrudan ilişkili bir etkinlik türüdür.

\section{MANTIĞIN NE'LiĞi}

Burada zihinsel hareketlerin bilimi olarak mantığın ne'liğini, klasik mantıkçılar açısından konumu itibarıyla ele alabiliriz. Antik Yunan'da Aristoteles tarafından doğru düşünmenin kurallarını bildiren bir yöntem olarak kurgulanan ve modern dönemde ise daha çok argüman oluşturmayla ilgili konuları inceleyen mantık bilimi ${ }^{5}$, bilimsel bilginin elde edilmesinde kendisine en güvenilen araçtır. Zira doğru bilgiye ulaşma çabasındaki fizikten metafiziğe kadar pek çok bilim dalında, doğru, tutarlı ve geçerli bir akılyürütme yapılması zorunluluğu vardır. Özdeşlik, çelişmezlik ve üçüncü halin imkansızlığı denilen evrensel ve zorunlu olduğu kabul edilen akıl ilkeleriyle varlık, dil ve düşünce arasında sabitlik ve değişmezlik tesis edildikten sonra zihnin sağlam bir kavramsal düşünmeyi ve bu kavramları kullanarak geçerli akılyürütmeler yapabilmeyi bilmesi gerekmektedir. İşte düşünce tarihinde Aristoteles'in Organon adı verilen eserleriyle, tüm insan akıllarının uzlaşarak doğruluğunu tasdik edeceği tümdengelimli bir akılyürütme biçimi yerleştirilmeye çalışılır. ${ }^{6}$ Kavramlar, önermeler ve akılyürütmeleriyle ilgili kurallardan ibaret olan bu düşünme tekniğinin, her insan için zihnin genel formu olduğu iddia edilmiştir. Daha açık bir ifadeyle $i k i$ değerli mantık olarak da adlandırdığımız bu biçimsel düşünme şekli, her insan zihnini aynı formda çıkarım yapmaya zorlayan ve aynı verilerle aynı sonuca ulaşmayı hedefleyen geçerli bir mantıksal yapı olarak varlığını yüzyıllar boyunca sürdüregelmiştir. Şu halde Antikçağ Yunan dünyasında Aristoteles tarafından sistemli hale getirilen mantığın, zihnin belli bir form içerisinde düşünmesini hedefleyen tek tip bir biçimsel yapı olduğu söylenebilir.

\section{ANTIKK ÇAĞDA SPOR}

Spor ${ }^{7}$ sözcüğünün XIX. yüzyılda İngiltere'de fiziksel hareketler anlamında kullanılmaya başlandığı kabul edilse de, fiziksel hareketler veya jimnastik kelimelerinin terim anlamında kullanılışını Antik Yunan'a kadar geri götürebiliriz. Bu dönemde jimnastik, hem her Yunan vatandaşının yapması gereken beden eğitimi hem de olimpiyatlarda yarışan atletlerin ${ }^{8}$ eğitimi anlamında kullanılırdı. Bu eğitime, bedenin forma girmesini sağlayan fiziksel etkinlik olarak çocukluk döneminde başlanır ve belli bir disiplin içerisinde sürdürülen eylemler olarak devam ettirilirdi.

\footnotetext{
${ }^{5}$ Scott M. Sullivan, An Introduction to Traditional Logic, Booksurge Publishing, USA, 2005, s. 1; Roy T. Cook, A Dictionary of Philosophical Logic, Edinburgh University Press, 2009, s. 174

${ }^{6}$ Aristotle, Analytica Priora, (The Basic Works of Aristotle içinde), ed. Richard McKeon, Modern Library Paperback Edition, 2001, s. 65.

${ }^{7}$ Spor kelimesi Fransızca sport sözcüğünün Türkçe karşılığıdır. Spor kelimesi sözlükte şöyle açıklanmaktadır: "Bedeni veya zihni geliştirmek amacıyla kişisel veya toplu olarak gerçekleştirilen, bazı kurallara göre uygulanan hareketlerin tümü." Türkçe Sözlük, TDKY, 11. Baskı, Ankara, 2011, s. 2158.

${ }^{8}$ Atlet kelimesi Yunanca'da, bir ödül için yarışan kimse anlamında kullanılır. Jernej Pisk, "What is Good Sport? Plato's View?", Acta Univ. Palacki., Gymn., 2006, vol. 36, s. 67
} 
Böylece düzenli yapılan fiziksel hareketlerle bedenin ideal formu muhafaza edilmeye çalışılırdı.

Buna göre spor, devletin vatandaşlarının her türlü eğitim programlarında yer alan bir derstir. Spor yalnızca olimpiyatlarda yarışacak olan atletlere yaptırılan idmanlar olmayıp, devleti koruyan bekçiler/savaşçılar ve devleti yöneten filozof idareciler dahil her Yunan vatandaşının çocukluğundaki ilk eğitiminden itibaren yaptırılan pratik bir derstir. İlk eğitimin müzik ve sporla başlaması gerektiğini Platon ve Aristoteles açıkça söylemektedirler. Sözgelimi ütopik olmakla birlikte siyaset felsefesi alanında meşhur bir eser olan Devlet'te, Platon, çocukların eğitimini müzik ve sporla başlatır. Ona göre müzik eğitimi beden eğitimiyle tamamlanmalıdır. Zira her iki disiplin de, gençlerin ruh ve bedenlerinin ölçülü bir yapıda olmasını sağlar. Ölçülü ve akıllı yapılan bir beden eğitimi, bedeni fiziksel açıdan güçlendirir. Eğer böyle bir eğitime başvurulmazsa, beden, hastalıklarla mücadele etmek zorunda kalır. ${ }^{9} \mathrm{Bu}-$ rada ruh-beden birlikteliği spor ve müzikle niceliksel boyutta bir ölçülülük kazanmakta ve elde edilen dinginlikle zihnin doğru çalışmasına imkan sağlamaktadırlar.

Bu bağlamda Platon'a göre, hem müzik hem de jimnastik eğitimi almanın asıl amacının; zihin eğitimi olduğuna işaret edebiliriz. Daha açık bir ifadeyle bu iki eğitim şekli, insanda, coşkun bir yürekle beslenen bilim sevgisini doğuracaktır. İnsanın içindeki iki güç olarak müzik ve jimnastik, telli bir saz üzerindeki iki tel gibidir yani insanı bir gevşeten bir geren düzenek olarak bu iki disiplin, bedende ve zihinde ahengi sağlayacaktır. ${ }^{10}$ Eğer tek başına müzik eğitimi alınırsa, ruh hali gevşek yapıda olacaktır. Buna karşılık sadece beden eğitimine devam edilirse gergin bir ruh haliyle karşılaşılacaktır. Bu durumda matematiksel bir yapısı olan müzik, insanın ruhunu rahatlatırken, beden eğitimi rahatlayan ruhsal yapıyı gerilim içine sokarak dengenin korunmasına yardım edecektir.

Platon'a göre çocukluk ve gençlik dönemlerinde bedenle birlikte ruhsal dengenin gözetildiği eğitimle, bilim ve felsefe eğitimine hazırlık yapılmış olacaktır. Öncelikle gençlerin bedenlerinin eğitilmesi, bedenin felsefeye iyi bir hizmetçi olarak geliştirilip erginleştirilmesine yol açacaktır. ${ }^{11}$ Burada ayrıca Platon devletin güvenliğini sağlayacak olan bekçilerin de, yukarıda bahsedilen iki tür eğitimden geçirilmesi gerektiğine dikkat çeker. Müzik ve beden eğitimi (gymnastic/physical training) ${ }^{12}$, bekçilerin ruh ve beden olarak güçlü olmalarını sağlayacaktır. Aslında filozoflar gençliklerinde savaşçı atletler (athletes) olarak eğitilirdi. Bunun için doğan ve ölenle uğraşan, bedenin bozuluşuyla ilgilenen jimnastik eğitimi, en az diğer bilimlerin öğretimi kadar vazgeçilmezdir. ${ }^{13} \mathrm{O}$ halde Platon için spor, sadece fiziksel bir etkinlik değil, bedene ve ruha, ölçülü ve denge-

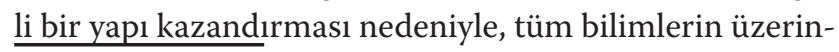

${ }_{9}$ Platon, Devlet, Çeviren: Sabahattin Eyüboğlu, M.Ali Cimcoz, Iş Bankası Yayınları, İstanbul, 1999, 403a-411e, s. 86-93.

${ }^{10}$ Platon, Devlet, 403a-411e, s. 86-93.

11 Platon, Devlet, 498b, s. 169

12 Platon, Devlet, 376e, s. 64.

${ }^{13}$ Platon, Devlet, 521e, s. 189. de yer alan asıl felsefe eğitimi için zorunlu bir eğitimdir.

Eğitimde sporun önemine dikkat çeken Aristoteles, ruh ve beden ilişkisini açıklarken de fiziksel hareketlerin etkisine değinir. Sporu insan etkinliklerinin en üst olanına en yakın olarak konumlandıran Aristoteles, düşüncenin ürettiği en yüksek bilgi kadar olmasa bile onun, insana verdiği özgürlükle ve oyunun kazandırdığıyla ciddi bir etkinlik olduğu görüşündedir. Onun devlet anlayışında fiziksel hareketlerle bedenini geliştirmiş olan erkek vatandaşların sosyal rolleri, diğerlerine göre daha güçlüdür. ${ }^{14}$ Sözgelimi bedenleri gelişmiş ve estetik bakımdan biçimli olan atletler -örneğin meşhur güreşçi Croton'lu Milo-, diğer vatandaşlara göre daha etkili bir konuma sahiptirler. ${ }^{15}$ Atlet spor yaptığı için hem enerji harcayarak hem de becerisini sergileyerek, iyi ya da kötü, bir beden olarak kendinin farkındalığını elde eder. Başka bir ifadeyle ona göre insan spor oyunlarıyla, kendi mükemmelliğini ortaya koyar. İnsanın mükemmelliği ise erdeme ve faydaya hizmet etmesiyle olur ki bu da; okuma-yazma, beden eğitimi (gymnastic exercises), müzik ve resim olmak üzere dört alandan oluşan eğitimin gerçekleştirilmesiyle mümkündür. ${ }^{16}$ Burada jimnastikle insanların, güçlü ve gözüpek hale getirilmesi amaçlanır. Özellikle savaşçıların cesur olmalarından ziyade güçlü bir bedensel yapıya sahip olmaları daha değerlidir. Zira cesur bir savaşçı, tehlikenin artması veya cephanenin azalması halinde cepheyi bırakıp kaçarken bedeni güçlü savaşçı ölünceye kadar mücadeleye devam etmektedir. ${ }^{17}$ Kısacası bedensel güçlülük, her alanda başarılı olmak için önceliğe sahiptir.

Bu bağlamda Aristoteles'in, hocası Platon'la aynı görüşte olduğunu yani fiziksel hareketlerle güçlendirilmiş bedene sahip insanın zihinsel etkinliklerde daha başarılı olacağını savunduğunu söyleyebiliriz. Ona göre akılyürütme eğitimi, jimnastik eğitiminden sonra gelir: "Alışkanlık-edindirme yoluyla eğitimin, akıl-yürütmeyle yapılan öğretimden önce gelmesi gerektiği besbelli olduğundan (nasil ki, ruhtan önce bedenin eğitimi gelir), çocuklarımızı jimnastiğe ve güreş çalışmaya göndermemiz gerektiği de açıktır; bunların ilki, vücudun kendisini düzenler, ötekiyse hareketlerini." ${ }^{18}$ Ayrıca burada onun ruh anlayışında bahsettiği, 'fantazya' (phantasma) kavramının yani duyumlar ve akılla bir bütün olan imgeleme yetisinin, sporcu açısından işlevine işaret edebiliriz. Çünkü duyum ile düşünce arasında bulunan imgeleme yetisini, sporcunun etkin biçimde kullanabilmesi oyunlarda başarılı olmasına yol açacaktır. ${ }^{19}$ Burada fantazya, adeta sporcunun rakibinin oyununda görmesi gereken stratejileri aydınlatan ve bu

\footnotetext{
${ }^{14}$ Aristotle, Rhetoric, (The Basic Works of Aristotle içinde), ed. Richard McKeon, Modern Library Paperback Edition, 2001, s. 1342-1343.

${ }^{15}$ C. D.C. Reeve, Action, Contemplation and Happiness, Harvard University Press, London, 2012, s. 111.

${ }^{16}$ Aristoteles, Politika, Çeviren: Mete Tunçay, Remzi Kitabevi, 6. Baskı, İstanbul, 2002, s. 235-237.

${ }^{17}$ Aristoteles, Nikomakhos'a Etik, Çeviren: Furkan Akderin, Say Yayınları, I. baskı, Istanbul, 2014, s. 72

${ }^{18}$ Aristoteles, Politika, s. 235-237

${ }^{19}$ Stravroula Roumbou, "Aristotle's Concept of Mental Imagery in Sports",

Psychological Though, PsychOpen Publishing Psychology, 2017, s. 54.
} 
bilgilerle oyun kurmasına imkan veren bir yeti olarak anlaşılabilir. Ona göre jimnastikle bedensel yapının yanı sıra insan hareketlerinin de forma girmesi ve ölçülü olmayı alıșkanlık edinmesi, akılyürütmelerinin öğretildiği zihinsel gelişimde kolaylık sağlanacaktır.

Aristoteles beden eğitiminin gerekliliğini öne sürmekle birlikte çocuğun vücudunu ve doğal görünüşünü bozan atlet yetiştirmeye yönelik eğitimi, genel beden eğitiminden ayırmaktadır. Ona göre beden eğitiminde doğru ve yanlış olan uygulamalar vardır. Jimnastik dengeli yapılmazsa, bedenin doğal yapısı zarar göreceğinden ruhsal ve zihinsel yapı da bundan etkilenecektir. Bu nedenle ergenliğe kadar çocuğa, hafif ve kolay fiziksel hareketler yaptırılarak vücudun büyümesine engel olunmamalıdır. ${ }^{20}$ Başka bir ifadeyle zihinde ve bedende ölçülülüğün muhafaza edilebilmesi için dengeli bir şekilde spor eğitimi verilmelidir: "Zihnin ve bedenin aşırı ölçüde çalıştırılması hiçbir zaman birleştirilmemeli; bunların her biri ötekine karşıt bir yönde işler, beden çalışması zihnin, zihin çalışması bedenin gelişmesini engeller." ${ }^{21}$ Yani aşırı derecede yapılan spor, düşüncenin sağlıklı işlemesine engel teşkil eder. Zira sadece bedenin çalışması ve aklın kullanılmaması, fiziksel açıdan güçlü ancak aklı zayıf kişileri ortaya çıkartır. Bunun aksi durumunda ise düşünme yetisi güçlü ancak bedenen zayıf insanlarla karşılaşmaya neden olur. Açıkçası Aristoteles sporu, daha çok kişinin fiziksel gücünü geliştirmesi bakımından incelerken aynı zamanda onun zihinsel ve ahlakî gücünü de artırmasına daha fazla önem vermektedir.

\section{SPOR VE MANTIK}

Gelinen bu noktada spor ve doğru düşünme becerisini geliştiren bilim olarak mantık arasında ne tür bir ilişkinin kurulabileceğini sorabiliriz. Acaba mantık, sezgisel düşünme, yaratıcı düşünme, eleştirel düşünme gibi düşünme formlarıyla spor yapan kişilere katkı sağlayabilir mi? Veya spordaki mücadele, rekabet, oyun gibi kavramların, mantıksal düşünme açısından ne ifade ettiği incelenebilir. Her ne kadar spor ve mantık, birbirinden ayrı eylem formları olarak görünse bile, hem form verme ve ölçülülüğü hedefleme bakımından ortaklık hem de birbirlerinin gelişimine katkı sağlama bakımından aralarında bir tür girişimliliğin olduğu açıktır.

Mantık biliminin spor bilimiyle ilişkisi, sporcunun beden eğitiminde tutarlı, geçerli çıarımlar yapabilmesi kadar özellikle yarışmalarda çeşitli düşünme biçimlerini uygun tarzda kullanarak başarılı olmasının yollarını öğretmesiyledir. Klasik mantığın ilk konusu; kavramsal düşünmeye yöneliktir. Mantık yargılardan oluşan çıkarımlara ulaşabilmek için önce kavramların doğru biçimde inşa edilmesini amaçlar. Bunun için varlıkların ortak (cins) ve ayrılan (tür) özsel ve ilintisel özelliklerinden hareketle bölme ve sınıflandırma yapılmasıyla, şeylere dair, evrensel ve zorunlu kavramların zihinde ve dilde varlığından bahsedi-

\footnotetext{
${ }^{20}$ Aristoteles, Politika, s. 237-238.

${ }^{21}$ Aristoteles, Politika, s. 238.
}

lir. Aynı zamanda her kavramın mahiyeti, onun tanımını verir. Böylece her tanım, şeylerin kavramsal içeriğini teşkil eder. Bir bilimde kavramların ve tanımların bilinmesi ise o bilimin temel hususlarının bilinmesi anlamına gelir. $^{22}$ Buna göre spor biliminin kavramlarının ve onlara dair tanımların bilinmesi, sporcuda, fiziksel hareketlerin öğrenilmesinde ve tatbikatında doğru formların kazandırılmasını sağlar. Daha açık bir ifadeyle mantıksal düşünme, kavramların doğru, açık ve net olarak düşünülmesini öğrettiği için sporcu, fiziksel hareketlerle birlikte oyuna dair her türlü kavramı ve onların tanımlarını açık ve seçik olarak düşünebilmeyi öğrenir. Beden eğitimi öğreticisinin kullandığı kavramların, sporcu tarafından doğru anlaşılması gerekir. Aynı zamanda kavramsallaştırma yapabilme yani somuttan soyuta giderek düşünebilme, sporcunun, oyun içerisindeki somut durumları soyutlaştırarak kavramsallaştırabilmesine yarar. Kavramsal düşünme yerleştirildikten sonra ise bunların biraraya getirilmesiyle oluşan yargılar ve çıkarımların öğretilmesi gelir.

Esasında kavramlar birlikteliği olan bilgi, varolanların çeşitli çıkarımlarla ifade edilmesinden ibarettir. Zihin kavramlar arasında çeşitli özellikleri düzenleyerek bağ kurduğunda yargıya ulaşır ve yargılar arasında da yine çeşitli ölçütlere göre bağ kurarak çıkarımlar elde eder. İşte insanın iradeye dayanan eylemleri, bir bilgiyle ilişkili olarak bu şekilde ortaya çıkar. ${ }^{23}$ Buna göre sporcu, ilgilendiği sporla ilgili kavramlar arasında, bir bilgiye dayanan bağ kurarak yargılara ulaşır ve yine o, yargılarını biraraya getirerek yaptığ 1 çıkarımlarla oyun içerisinde doğru kararlar alabilir. Her yargıda, yargıda bulunanın seçimi vardır. ${ }^{24}$ Dolayısıyla sporcu, mantıksal düşünme biçimiyle fiziksel hareketlerinde veya spor oyunlarında rakibini mağlup etmek için doğru tercihler yaparak doğru çıkarımlar yapabilmelidir. Mantık biliminin spor bilimlerine katkısı, sporcunun bilgisini doğru bir formda düşünerek eylemlerini ortaya koyabilmesi bakımındandır.

Spor ve mantık bilimleri arasındaki bir başka bağlantı, yaratıcı, eleştirel ve sezgisel düşünme biçimleri yönünden kurulabilir. Yaratıcı düşünme, bireyin karşılaştığı sorunlarda veya herhangi bir konuda, öğrendiklerini aşarak yeni ve özgün bir düşünce üretebilmesidir. ${ }^{25}$ Sporcunun akli çıkarımlarla birlikte hayal gücünü de kullanmasını gerektiren yaratıcı düşünme biçimi, her türlü spor aktivitesinde gerek oyun içerisinde meydana gelen problemlerin çözümünde gerekse de rakibin oyunlarının bozularak onun bilmediği bir oyun kurgulayarak yarışmanın kazanılmasını sağlar. Yaratıcı düşünme, herkesin düşündüğünden ve öğrenilmiş olanlardan farklı olarak yeni ilişkileri kavrayarak yeni bir düşünce üretmek olduğundan sporcu, hayal gücünü de kullanarak oyun esnasında öz-

\footnotetext{
${ }^{22}$ Geniş bilgi için bkz. R.E. Jennings, N. A. Friedrich, Proof and Consequence An Introduction to Classical Logic, Broadview Press, Peterborough, 2006.

${ }^{23}$ Necati Öner, Bilginin Serüveni, Vadi Yayınları, 2. Basım, Ankara, 2008, s. 28-29.

${ }^{24}$ Necati Öner, Bilginin Serüveni, s. 29.

${ }^{25}$ Mehmet Arif Özerbaş, "Yaratıcı Düşünme Öğrenme Ortamının Akademik Başarı ve Bilgilerin Kalıcılı̆a Etkisi", Gü Gazi Eğitim Fakültesi Dergisi, c. 31, S. 3, 2011, (675-705), s. 678
} 
gün ve geçerli oyunlar kurabilir.

Bunlara ilave olarak 'eleştirel düşünme biçimi' ifadesinde yer alan eleştiri, bir fikrin veya bir eylemin analizinin yapllarak yine bu düşünmenin veya eylemin benzerleriyle arasındaki farklılıkların tespit edilmesine ve ideal olanla kıyaslanmasına denilir. ${ }^{26}$ Beden eğitimiyle ilgili olarak eleştirel düşünme; "bir hareket hakkında savunucu ve mantıklı kararlar alabilmek için kullanılan yansıtıcı düşünme." ${ }^{27}$ şeklinde tanımlanmaktadır. Burada sporcu problem çözmede, eleştirel düşünmeden faydalanabilir. Tıpkı eleştirel düşünmede olduğu gibi problem çözme, genel bir stratejik bilgi olarak kabul edilebilir. ${ }^{28} \mathrm{Bu}$ anlamda eleştiri, sporcunun, kendi hareketlerini çözümleyerek hem rakibinin hareketlerine benzeyen veya ayrı olan taraflarının tespitini hem de ideal olandan eksikliklerini tayin edebilmesine imkan verir. Sporcu, özellikle oyunlar esnasında rakibinin kurguladığı oyunu hızlı bir şekilde düşünüp analiz ederek kendi oyununu kurgulayabilmesi böyle bir düşünme yeteneğine sahip olmasıyladır. Dolayısıyla mantık bilimi, sporcuya, eleştirel düşünme yeteneğinin kazandırılmasını sağlar.

Diğer taraftan sporu odağa alarak mantık bilimini düşündüğümüzde, Platon ve Aristoteles'in "zihinsel eğitim” için bedensel hareketlerin gerekliliğine dair görüşlerine ilave olarak sporun kazandırdığı başta "oyun kurgulama" ve "mağlup etme/rakibini alt etme" gibi pratiğe dönük düşünme biçimlerinin bilhassa argümantasyon kurmada ve diyalektik düşünmede teorik olarak katkısı olabilir. Sözgelimi diyalektik düşünme, iki değerli klasik mantıksal düşünme gibi mekanik bir ispat yöntemi değildir. Başka bir ifadeyle diyalektik düşünmede, formel bir dille belirlenen ve doğruluğu denetlenebilen bir akılyürütme biçiminden bahsedilemez. Zira bir keşif yöntemi olarak diyalektik düşünmede, sabit olanın aksine antitez ortaya konularak senteze ulaşılmaya çalışılır. ${ }^{29}$ Buna göre sporcu, rakibinin oyununu bozacak oyun kurgularken, onun tezine karşılık antitez oluşturmaya çalışmaktadır. Daha sonra ise kendisine oyunu kazandıracak planını çıkartırken adeta tez ve antitezden senteze ulaşmaktadır. Şu halde söz konusu çıkarımsal düşünme biçimlerinin uygulanmasında, tartışmalarda ya da münazaralarda tartışmacı, çeşitli oyun tekniklerini kullanarak başarı elde edebilir.

\section{SONUÇ}

Sonuç olarak spor ve mantık arasındaki ilişkiyi araştırmaya yönelik bu çalışmada mantığın, düşünceleri açık ve se-

\footnotetext{
${ }^{26}$ A. Baki Güçlü, Erkan Uzun, Serkan Uzun, Ü. Hüsrev Yolsal, "Eleştiricilik Maddesi”, Felsefe Sözlüğü, Bilim ve Sanat Yayınları, Ankara, 2002, s. 466.

${ }^{27}$ Fatma Saçlı-Gıyasettin Demirhan, "Beden Eğitimi ve Spor Öğretmenliği Programında Öğrenim Gören Öğrencilerin Eleştirel Düşünme Düzeylerinin Saptanması ve Karşılaştırılması", Spor Bilimler Dergisi Hacettepe J. Of Sport Sciences, 19 (2), 2008, (92-110), s. 94

${ }^{28}$ Ron E. McBride, "Critical Thinking-An Overview With Implications For Physical Education", Journal On Teaching In Physical Education, 1991, 11, (112-125), s. 114

29 Şafak Ural, “Diyalektik Düşünce ve Mantık”, Felsefe Arkivi, S. 28, İstanbul, 1991, s. 5 .
}

çik hale getirmeyi hedefleyen biçimsel düşünme tarzının sporculara pek çok açıdan yarar sağlayabileceği anlaşılmıştır. Düşüncede sağlam bir zemin kurarak neyi düşündüğünü bilmeyi ve düșündüğü anlamın tam bir şekilde sahibi olarak insanlara iletebilmeyi amaçlayan mantıksal düşünme biçimi, sporcunun fiziksel hareketlerinde veya spor oyunları içerisinde eylemlerinin düşünsel zeminini sağlam bir şekilde kurgulamasına katkı sağlayabilir. Ayrıca tümdengelimli, yaratıcı, eleştirel düşünme biçimlerini bilip uygulayan bir sporcu, kurguladığı her oyunda veya rakibinin oyununun çözümlenmesinde seri bir düşünme biçimine sahip olarak başarılı bir oyun sergileyebilir. Burada özellikle futbol, basketbol gibi takım oyunlarında birlikte veya münferid olarak kurgulanan taktikler, sporcunun kendi bilgi ve becerilerinin üzerine çıkarak başarılı olmasına yol açabilir. Buna karşılık spor bilgisine sahip olan kişilerde, mantıksal düşünme biçiminin pratik yanı güçlü olduğu gibi münazara türü tartışmalarda oyun kurgulayarak sonuca gitmesi daha kolay olabilir.

\section{KAYNAKÇA}

Aristoteles, Politika, Çeviren: Mete Tunçay, Remzi Kitabevi, 6. Baskı, İstanbul, 2002.

Aristoteles, Nikomakhos'a Etik, Çeviren: Furkan Akderin, Say Yayınları, I. Baskı, İstanbul, 2014.

Aristotle, Analytica Priora, (The Basic Works of Aristotle içinde), ed. Richard McKeon, Modern Library Paperback Edition, 2001.

Aristotle, Rhetoric, (The Basic Works of Aristotle içinde), ed. Richard McKeon, Modern Library Paperback Edition, 2001.

Cook, Roy T. A Dictionary of Philosophical Logic, Edinburgh University Press, 2009.

Erdemli, Attila, Temel Sorunlarıyla Spor Felsefesi, E Yayınları, III. Basım, İstanbul, 2016.

Güçlü, A. Baki, Erkan Uzun, Serkan Uzun, Ü. Hüsrev Yolsal, “Eleştiricilik Maddesi”, Felsefe Sözlüğü, Bilim ve Sanat Yayınları, Ankara, 2002

Jennings, R.E., N. A. Friedrich, Proof and Consequence An Introduction to Classical Logic, Broadview Press, Peterborough, 2006.

Mcbride, Ron E., "Critical Thinking-An Overview With Implications For Physical Education", Journal On Teaching In Physical Education, 1991, 11, (112-125).

Öner, Necati, Bilginin Serüveni, Vadi Yayınları, 2. Basım, Ankara, 2008,

Özerbaş, Mehmet Arif, "Yaratıcı Düşünme Öğrenme Ortamının Akademik Başarı ve Bilgilerin Kalıcılığa Etkisi", GÜ Gazi Eğitim Fakültesi Dergisi, c. 31, S. 3, 2011, (675-705).

PISK, Jernej, “What is Good Sport? Plato's View?", Acta Univ. Palacki., Gymn., 2006, vol. 36.

Platon, Devlet, Çeviren: Sabahattin Eyüboğlu, M.Ali Cimcoz, İ̧̧ Bankası Yayınları, İstanbul, 1999.

Plato, Second Alcibiades, (Complete Works içinde), ed. John M. Cooper, Hackett Publishing Company, USA, 1997.

Plato, Rival Lovers, (Complete Works içinde), ed. John M. Coo- 
per, Hackett Publishing Company, USA, 1997.

Plato, Alcibiades, Complete Works içinde), ed. John M. Cooper, Hackett Publishing Company, USA, 1997.

Plato, Crito, Complete Works içinde), ed. John M. Cooper, Hackett Publishing Company, USA, 1997.

Reeve, C. D.C., Action, Contemplation and Happiness, Harvard University Press, London, 2012.

Roumbou, Stravroula, "Aristotle's Concept of Mental Imagery in Sports", Psychological Though, PsychOpen Publishing Psychology, 2017.

Saçlı, Fatma-Gıyasettin Demirhan, “Beden Eğitimi ve Spor Öğretmenliği Programında Öğrenim Gören Öğrencilerin Eleştirel Düşünme Düzeylerinin Saptanması ve Karşılaştırılması", Spor Bilimler Dergisi Hacettepe J. Of Sport Sciences, 19 (2), 2008, (92-110).

Sullivan, Scott M., An Introduction to Traditional Logic, Booksurge Publishing, USA, 2005.

Tekin, Ali, Gülcan Tekin, "Antik Yunan Dönemi: Spor ve Antik Olimpiyatlar Oyunu", Tarih Okulu Dergisi, Yıl: 7, Sayı: XVIII, Haziran 2014, (ss. 121-140).

Türkçe Sözlük, TDKY, 11. Baskı, Ankara, 2011.

Ural, Şafak, "Diyalektik Düşünce ve Mantık”, Felsefe Arkivi, S. 28, İstanbul, 1991. 